\title{
NIETZSCHE AND HERMENEUTICAL THINKING: FINITUDE AND TRUTH ${ }^{1}$
}

Rebeca Furtado de Melo (Colégio Pedro II) ${ }^{2}$ rebecafurtado7@gmail.com

\begin{abstract}
The question of whether Nietzsche should or at least could be incorporated into the hermeneutical tradition has been a debate for many scholars in the last decades. Differing claims, both for and against, have been advanced by people such as Vattimo, Davey, Babich and Grondin. This work attempts to discuss some of these claims, addressing the hermeneutical background to Nietzsche's thought focusing on two key concepts of his philosophy: finitude and truth. I argue that Nietzsche's philosophy can be understood as hermeneutical thinking since it assumes the radical purpose to think our finite situation (in both epistemological and existential senses) in a way that is very close to the hermeneutical circularity of human understanding. I also argue that this interpretation allows such polemical theses as the will to power, perspectivism, and "theory of errors" to become comprehensive as a whole, and mutually compatible.
\end{abstract}

Keywords: Hermeneutics; Nietzsche; truth; finitude; hermeneutical circle.

To ask whether a thinker belongs in a specific tradition is at the same time to ask what defines this tradition. This means that to discuss whether Nietzsche should, or at least, could, be incorporated into hermeneutic tradition, is at the same time to discuss what hermeneutical thinking really means.

\footnotetext{
${ }^{1}$ Recebido em: 21-03-2017/ Aprovado em: 11-10-2017 / Publicado on-line em: 08/02/2018.

${ }^{2}$ Rebeca Furtado de Melo é Professora do Departamento de Filosofia do Colégio Pedro II, Rio de Janeiro, RJ, Brasil.
} 
Thereby, the claim about Nietzsche and hermeneutics is not trivial, since it reveals its importance in a philosophical inquiry. To think about whether Nietzsche is (or is not) a hermeneutic thinker is not only a historical-academic activity, which tries to show where or when some concepts were born. As Babette Babich (2010) has emphasized it should not only be a question of "copyrights" and influences or originality between philosophers3. Rather this kind of task seems only to have real significance when it helps us better to understand both: the author and the tradition, as well as the phenomenon that they intended to describe.

For this purpose, unlike other works about Nietzsche and hermeneutics, this paper will not stress the link between interpretation and hermeneutics and the undiscussed presence of an interpretation theory throughout Nietzsche's work. Or, at least, it will not be the main focus of discussion. Rather, this work attempts to show as even the theory of interpretation in Nietzsche seems better understood when we follow the transcendental aspect of it and Nietzsche's concern to recognize human limits. But since this concern is, at the same time, an important critique to the strong pretentions of Kant's position regarding synthetic a priori judgment, Nietzsche's reflections about the transcendental seem more a recognition of the hermeneutical circularity of the human condition. In this sense there are three main steps on our path: 1) how transcendental philosophy

\footnotetext{
3 "By the claims of influence - this is especially characteristic of the modern litigations and no less proprietary age-one claims priority and means to insist upon intellectual tribute, a kind of copyright on an idea or even genius. Hence one is compelled to argue against influence in order to affirm novelty. Such ascriptions of innovation (or denials of the same) are duly registered to and debited from a kind of scholarly patent office. Hence we do better to ask if there was such a debt between contemporary representatives of the hermeneutic tradition and Nietzsche to begin with" (Babich 2010, 222).
} 
is concerned to recognize our limitations, i.e., the limits and condition of the human knowledge; 2) how hermeneutics is a kind of radicalization of transcendental philosophy, once it assumes not only our limitations regarding knowledge but also the characteristic circularity of all human understanding; 3) asking whether Nietzsche can be thought of as a hermeneutic philosopher, or in other words, if his thought is fundamentally concerned with the challenge to think the human condition from its finitude in epistemological and existential senses.

To discuss and to articulate these three steps there are two classical philosophical concepts that seems to be fundamental: finitude and truth. While these concepts always have been present in the history of philosophy, they assume a really special importance when the transcendental project is initiated by Kant. Finitude and truth are no longer thought of as opposite and exclusive concepts, but rather correlated and even inseparable, once truth comes to be thought in connection with the conditions of the possibility of human knowledge, i.e., once the constitutive limits of the finite knower are determined. It is not hard to see clearly in the Kantian project both a claim for assuming the limits or the conditions of the possibility of human knowledge and at the same time the vindication this is the only way to ground metaphysical knowledge and any possibility of objectivity in the mathematical-empirical sciences ${ }^{4}$.

\footnotetext{
4 "My doctrine of the ideality of space and time, therefore, so far from making the whole world of the senses into mere illusion, is rather the only means of securing the application to real objects of one of the most important kind of knowledge, namely that when mathematics expound a priori, and of preventing it from being held to be mere illusion, because without this observation it would be quite impossible to decide whether the intuition of space and time, which we take from no experience and which yet lie in our representation a priori, were not mere chimeras of the brain made by us to which no object correspond, at least not adequately..." (Kant 1953: Note III, p. 49)
} 
According to Kant, metaphysics as a science is concerned with the transcendental as the condition of the possibility of human knowledge; it is concerned with limits, human constrains and therefore with our finite reason ${ }^{5}$. Thus the Kantian transcendental project is to be understood as the claim that we are limited to the "human standpoint" 6 . However, Kant seems to try to go beyond this limitation when he claims to have determined and demonstrated in which sense the forms of intuition and categories are a priori, and therefore, necessary and universal. It is precisely in this tension that we can perhaps position Nietzsche's philosophy.

\section{NIETZSGHE VERSUS KANT}

In the last few years, many scholars have engaged in research and debate about the relation between Nietzsche and Kant. Since it is possible (or even probable) that Nietzsche only studied Kant through commentators rather than reading Kant's work directly ${ }^{7}$, it is not surprising that new works are for the most part devoted to the study of the relation between Nietzsche and some of the neo-Kantian.

\footnotetext{
${ }^{5}$ Even though very different in most respects, Henry Allison's and Heidegger's interpretations seem to agree about this aspect: that the Kantian project arises from the admission of our finite condition (in opposition to God-like infinity - intuitive intellect). See: This discussion by Zuckert (2007, p.213-231), especially note 4, p. 280 and Allison (1983, especially p. 65 onwards).

${ }^{6}$ This term was used by Kant himself in the Critique of Pure Reason. Just before A27/B43, (1964, p.71): "It is, therefore, solely from the human standpoint that we can speak of space, of extended things, etc. If we depart from the subjective condition under which alone we can have outer intuition, namely, liability to be affected by objects, the representation of space stands for nothing whatsoever. This predicate can be ascribed to things only in so far as they appear to us, that is, only to objects of sensibility. The constant form of receptivity, which we term sensibility, is a necessary condition of all the relations in which objects can be intuited as outside us..."

${ }^{7}$ For this discussion and some others references about the matter see the beginning of the paper and the first note of Bailey (2013).
} 
However, many of those works attempt to join Nietzsche to a project of "naturalization of the transcendental" carried out especially by some philosophers and physicists of the $19^{\text {th }}$ century such as Albert Lange and Hermann von Helmholtz, for example ${ }^{8}$. This project consists broadly of assuming that human knowledge has some constraints, but that these constrains should be explained by the research of the developing empirical sciences rather than a transcendental critique in the Kantian sense. This kind of interpretation of Nietzsche now has many representatives ${ }^{9}$. One exception to this view is Michael Green ${ }^{10}$ who points out the relation of Nietzsche with Afrikan Spir (1837-1890) ${ }^{11}$. What is notable about the Spir's work is that it defends the necessity of a stronger philosophical consideration of the transcendental by pure reason (in the sense of Kantian metaphysical speculation), claiming that the naturalistic approach is incoherent. It is interesting to note that Spir was already an exception in his time, when the debate about the appropriation of the Kantian philosophy already was predominantly naturalistic ${ }^{12}$. In this sense, we could ask how the dispute about whether we should read Nietzsche as naturalist or transcendental philosopher is a kind of doubling of the debate surrounding Kant in the second

\footnotetext{
${ }^{8}$ For a discussion about this historical panorama, see: Lopes (2008, p. 42 -84).

${ }^{9}$ One important work in this sense was "Lange and Nietzsche" by G. Stack, published in 1983. But we could cite others like Richardson (2013), and also the pro-naturalistic interpreters of Nietzsche such as M. Clark and B. Leiter.

${ }^{10}$ There are other accounts of Nietzsche's relation with Kant that could be cited here, for example, Doyle 2005 or the already cited work of Bailey 2013. I have singled out Green's work since it occupies a more fundamental place in my argument in this paper.

11 These are Forschung nach der Gewissheit (1869) and Denken und Wircklich, published in I873 and in a new edition in 1877.

${ }^{12}$ Small claims that Spir could not be considered a neo-Kantian since he defends strong claims about the thing-in-itself. But even being this way, he recognizes that Spir's philosophy is allowed only by a criticism to the Kant and Herbart's doctrines (Small 1994, p. 87).
} 
half of the $19^{\text {th }}$ century $^{13}$.

Green carefully shows in his book the strong relation of Nietzsche's to Spir's thought in order to support the claim that Nietzsche's engagement with Spir's philosophy is incompatible with his complete absorption into naturalism. One of the most important critiques Spir makes of Kant (one that is appropriated by Nietzsche, though in a reverse way) is that Kant failed to construct a bridge between the thing-in-itself and the phenomenon by his account of time. The principal argument is that we cannot deny the reality of change and thereby we must assume that succession and time are real rather than ideal. Spir points out that becoming requires that changes must exist in time beyond of the subject. Since even our ideas appear to us as successive, i.e., they always are given in a specific order, then they must occur in time. Accordingly, time cannot be an a priori form of intuition; instead, we cannot deny its reality. However, if so understood, then there is a fundamental incompatibility between the becoming that happen in time, the temporal process of transcendental synthesis and the apperceptive self, that stands outside time. (Green 2010, p. 50).

For Spir, unlike Kant, the only truly a priori element of the transcendental subject is the principle of identity which is applied to the experienced changes, and that is why Spir claims that "human knowledge has within itself a 'fundamental antinomy'. It has elements of being and becoming, but the two cannot be bridged." (Green 2010, p. 50) ${ }^{14}$.

\footnotetext{
${ }^{13}$ What is important about Spir for this specific discussion is his defence that only a transcendental reflection could enable us to ground empirical research once causality (used in naturalist explanations) is derived from the identity principle (the only rightfully a priori element of the transcendental subject). For this debate and the engagement of Nietzsche with both sides see: Mattioli (2013).

${ }^{14}$ Spir's point is a complex one that deserves a specific and specialized discussion of Spir, Herbart Cont.
} 
Spir denies any kind of knowledge to the human being, either through a realistic approach or through transcendental idealism, because both include antinomies in their constructions ${ }^{15}$. This conclusion will take Spir to his radical theory that we can only guarantee secure knowledge about the principle of identity, a kind of Parmenidian project which divides the world completely between appearance and absolute reality. Once there is an impassable gap between the logic-judgmental schema and the empirical reality we cannot have any objective knowledge. And therefore transcendental idealism is able to save neither the objectivity of the phenomena nor the description of its own a priori forms or categories. Accordingly, all knowledge about phenomena is intrinsically false because empirical knowledge necessarily involves antinomies. However, for the sake of saving some space for truth in a stronger sense and knowledge as secure, deep-seated and universal, Spir defends that true knowledge involves only the purely logical principles ${ }^{16}$.

Nietzsche strongly criticises this last conclusion. There are many passages and aphorisms, mainly in the $70^{\prime} \mathrm{s}^{17}$, that are supposed to be an answer directly to Spir, who "be-

and Kant. It would be not possible carryout this task here and it is not even necessary since it has been done, including in a Nietzchean context, in other places, as for example the already cited Green, Small and Mattiolli works. Here it only interests me in showing roughly what Nietzsche will derive from this discussion, to defend my point about hermeneutics put forward in this paper.

${ }^{15}$ This debate he inherited from Herbart's "trilemma" that arises from the concept of change (Small 1994, p. 96).

${ }^{16}$ In this context, the term "logics" is not used in a formal sense, but rather in an ontological sense. It points out the principles that determine our ontological understanding of reality.

17 Texts collected as Philosophy in the Tragic Age of the Greeks, written in 1873, have clear references to the work of Spir, pointed out his critics to Parmenides in relation to the logical principle of identity. This is why Spir is usually called as the "logician" by Nietzsche, mainly, in Human, all too Human. (See specially aphorisms 16, 17, 18, 19, 131.) 
lieves in the absolute status of logical truth" (Small 1994, p. 88). But on the other hand, Nietzsche assumes the idea that it is not possible to ultimately justify and ground our knowledge, either in an empirical, or in a transcendental way. In aphorism 19 of Human, All too Human, for example, Nietzsche gets in a frontal discussion with these problems raised by Spir, when he says:

[...] The assumption of plurality always presupposes the existence of something that occurs more than once: but precisely here error already holds sway, here already we are fabricating being, unities which do not exist. - Our sensations of space and time are false, for tested consistently they lead to logical contradictions. The establishment of conclusions in science always unavoidably involves us in calculating with certain false magnitudes: but because these magnitudes are at least constant, as for example our sensation of time and space, the conclusions of science acquire a complete rigorousness and certainty in their coherence with one another; one can build on them - up to that final stage at which our erroneous basic assumptions, those constant errors, come to be incompatible with our conclusions, for example in the theory of the atoms. [...]

When Kant says 'the understanding does not draw its laws from nature, it prescribes them to nature', this is wholly true with regard to the concept of nature which we are obliged to attach to nature (nature $=$ world as idea, that is as error), but which is the summation of a host of errors of the understanding. - To a world which is not our idea the law of number are wholly inapplicable: these are valid only in the human world. (NIETZSCHE 1996, p. 22)

This aphorism is interesting for at least three reasons: 1) Nietzsche assumes Spir's critique of Kant, since he defends in the beginning of the passage the following: that the identity principle is a necessary projection of the human beings even to think the plurality, but this is ultimately an error, since, as Spir had argued, becoming and the principle of identity are antinomies. And yet, following the same argument, time and space are false since they are not logically 
grounded; 2) But on the other hand, he assumes that it is quite possible to produce and to ground scientific knowledge in an ungrounded (and therefore, false in a stronger sense) assumptions. This is strong evidence that Nietzsche does not deny any kind of knowledge whatsoever, but rather, on contrary, he claims that the results of science do acquire rigour and certainty in their relationship to each other, while the projecting that grounds it is shown as constant. It is clearly an assumption that objective knowledge is possible in the interior of a specific preunderstanding and pre-determination of what we understand as nature ${ }^{18}$; i.e., objectivity is possible only in relation to a particular pre-determined horizon; 3) And yet that Kant is right once he has noted that we always already apply to nature our own projection (even when it can have a stability enough to produce scientific knowledge). In this sense, since Human, all too human our transcendental situation is already clear to Nietzsche. But still he is also aware about the radical impossibility of grounding even the description of these constraints, as Kant had tried to do. It is clearly a claim for a more radical critique of our human situation, or our "standpoint", since it assumes the limits of this critique itself.

However, it is surprising that Green does not mention some aphorisms in which Nietzsche strongly argues in favour to our "transcendental conditions" as a result of contingent processes. As Beatrice Han-Pile says, this "empirical genesis" would be evidence of the robust naturalistic elements in the Nietzsche thought, as she puts it: "The 'tran-

\footnotetext{
${ }^{18}$ I shall return to this point later when I will try to quickly answer the main critique put by Grondin to the attempt to reading Nietzsche as hermeneutic philosopher.
} 
scendental' elements in perception have an empirical genesis: they have their causal conditions of possibility in the rise of new practices (such as societal life), and their necessity is only relative to these practices." (Han-Pile 2009, p. 194). Han-Pile calls Nietzsche's position "deflationary transcendental". And that is why, on the one hand, it assumes nonempirical pre-conditions for the perception of something, that is, a structure that determines how something can count as experience. On the other hand, this structure depends on specific empirical circumstances and thus if these circumstances change, the structure loses its normative power. In this sense this is another way to derail Kant's pretension about the a priori and thereby universality of the transcendental description of human reason. As HanPile articulates this, constraints can only be considered a priori from a "synchronic perspective". They are a priori while they are a structure which allows experience, but they are a posteriori since they are only allowed by specific practices; their validity cannot be justified on a "rational basis", but rather only in relation to these practices. That is why its universal validity cannot be defended and thus it only allows relative objectivity to the experiences within some particular preconditions.

John Richardson, in a more pro-naturalistic approach, defends something similar, when he says that "Nietzsche converts Kant's possibility-conditions into life-conditions." (Richardson 2013, p. 293). Without doubt, there are many places that Nietzsche uses terms like that ${ }^{19}$ in his work.

\footnotetext{
${ }^{19}$ Richardson provides the following list of places where this terms appears: "Lifecondition [Lebens-Bedingung]: BGE.188, A.25. Lebensbedingung: GS.110, BGE.4, BGE.62, BGE.268, BGE.276. Bedingung des Lebens: GS.110. Existence- condition [Existenz-Bedingung]: GS.1, GS.7, GS.335, EH.iv.4. Existenzbedingung: GM.i.10, EH.iv.4. Preservation-condition Cont.
} 
Nevertheless, reading these terms in a strictly biological sense, and "in broadly Darwinian terms" (Idem, p. 295), seems to lose track of Nietzsche's interests. In this regard, aphorism 354 of The Gay Science can be especially interesting:

[...] I may now proceed to the surmise that consciousness has developed only under the pressure of the need for communication; that from the start it was needed and useful only between human beings (particularly between those who commanded and those who obeyed); and that it also developed only in proportion to the degree of this utility. [...] Add to this that not only language serves as a bridge between human beings but also a mien, a pressure, a gesture. The emergence of our sense impressions into our own consciousness, the ability to fix them and, as it were, exhibit them externally, increased proportionately with the need to communicate them to others by means of signs. [...] My idea is, as you see, that consciousness does not realty belong to man's individual existence but rather to his social or herd nature; that, as follows from this, it has developed subtlety only insofar as this is required by social or herd utility. [...] This is the essence of phenomenalism and perspectivism as $I$ understand them: Owing to the nature of animal consciousness, the world of which we can become conscious is only a surface and sign-world; a world that is made common and meaner; whatever becomes conscious becomes by the same token shallow, thin, relatively stupid, general, sign, herd signal; all becoming conscious involves a great and thorough corruption, falsification, reduction to superficialities, and generalization. [...] (NIETZSCHE 1974, p. 298-300).

This aphorism claims that the development of speech and consciousness, both characteristic of the human being, were consequences of the necessity of communication and its utility for this animal that has a "social nature". In other

[Erhaltungs-Bedingung]: A.26, EH.iii.BT.3. Erhaltungsbedingung: A.16. Growth-condition [Wachsthums-Bedingung]: BGE.188, A.25. These uses of these terms in his books are the iceberg-tip to a great many more uses in his notebooks." (Richardson 2013, p. 293). He also points out in note 5 that "there are over 50 occurrences of either Existenz-Bedingung or Existenzbedingung in KSA volumes 9-13." (Idem). 
words, human beings had to develop some specific skills to live together and it allowed a special kind of communication through speech and consciousness. And yet this kind of communication only becomes possible once both language and consciousness are allowed by a common understanding of the world, that is always limited, and thereby to Nietzsche: superficial, symbolic and generalized. This shared and limited version of the world, which allows human beings live together, becomes possible not only through verbal communication but also meaningful looks, gestures and "sense impressions". It "fixed" the world by meaningful signs "externally", locating our "representation of the world" outside of ourselves. In this sense, for Nietzsche, our relation with things and with others (and yet our own conscious self-understanding) is possible thanks to a positing horizon that fixes shared and generalized versions of the world that guide our perceptions, speech and consciousness.

We could go further and suggest that ${ }^{20}$ here Nietzsche attempts to delimit a difference between the naturalist approach of his contemporaries, and his own. That is, he does not join strictly the project of naturalization of transcendental features as the specific biological and physiological development of the characteristics of the human being ${ }^{21}$. Rather his "phenomenalism and perspectivism" assumes the transcendental features as these understanding versions of the world as a common and shared limited-

\footnotetext{
${ }^{20}$ I owe thanks to Renan Cortez for a long discussion, about this aphorism in particular. Above all I owe to him the idea that was suggested in this paragraph, i.e., that Nietzsche is claiming for a distinction of the project of the naturalization of the transcendental when he use the phrase "phenomenomenalism and perspectivism as I understanding it".

${ }^{21}$ See BGE 15
} 
conceptualization, by which arise consciousness and speech. Thus, he assumes not only that biological organs or physiological structures are responsible for the way that we perceive the world but, in reverse, also claims a "socialcultural" origin for the transcendental limits of our relation with things and others.

On the other hand, even whether there is here a qualitative divergence from the naturalist explanation, there is still present a strong explanation in "empirical terms", as Han-Pile calls it. Namely, this shared horizon as well as the language and consciousness were developed in the human beings for the sake of communication and for its utility for the "human species". In this sense, Richardson's claim that there Nietzsche's philosophy can be read in "broadly Darwinian terms" is not discarded, since the development of external-vulgarized-shared world is a "life-condition" for humankind. This seems to claim that culture, language and comprehensibility were possible thanks to their utility for the human "animal" in its preservation-mutationdevelopment history. However the aphorism does not finish there, it continues in this way:

You will guess that it is not the opposition of subject and object that concerns me here: This distinction I leave to the epistemologists who have become entangled in the snares of grammar (the metaphysics of the people). It is even less the opposition of "thing-in-itself" and appearance; for we do not "know" nearly enough to be entitled to any such distinction. We simply lack any organ for knowledge, for "truth": we "know" (or believe or imagine) just as much as may be useful in the interests of the human herd, the species; and even what is here called "utility" is ultimately also a mere belief. Something imaginary and perhaps precisely that most calamitous stupidity of which we shall perish someday. (NIETZSCHE 1974, p. 300).

This last part of aphorism sounds strange and yet is de- 
cisive to this discussion. First of all, Nietzsche claims that assuming that the human relation to things is conditioned does not have anything to do with opposition, the separation between the subject and object and its problems. This distinction is a problem for "epistemologists" and it arises from the "snares of grammar"- the popular metaphysics! The Nietzschean critique of the "faith in grammar" 22 is well known, but this passage helps us understand what it can mean at all. The idea is that the epistemological problem of the relation between subject and object arises from the theoretical consideration that there is a primordial distance between both. However, this distance is derived from a grammatical rule. It would be foolish for Nietzsche to assume that our more complicated epistemic questions are just a simple and silly belief in grammar, if he does not admit an "ontological" place for language. Language is that by which we share our understanding of things and of ourselves with the others, and in this sense it is the custodian of our 'world'. This means that the way that we think and perceive the reality comes up through language. This notion is really clear in Beyond Good and Evil 20 when Nietzsche defends that the philosophical ideas are not "spontaneous", they are neither arbitrary nor a consequence of a radical critique of past thinkers. Rather, Nietzsche said that they arise from a "certain basic scheme of possible philosophies". This 'ground plan' works as a horizon that determines what is possible to be thought, and in this sense, "seems to be barred to certain other possibilities of world interpretation". And yet, Nietzsche claims that the development of history of philosophy that works in the in-

${ }^{22}$ See BGE 17/ 34 
terior of delimited possibilities is related to a kind of language that points out our pre-structure of understanding of the world. That is why Nietzsche ponders the great possibility that other philosophers that speak a quite different language (that does not share the same roots of the IndoEuropean languages) will 'look into the world differently' and will be found on other pathways of thought.

In this sense, the grammar is metaphysics of the people since it allows us to speak about our shared understanding, i.e., about the relation that we have with the things and with the others and with ourselves. That is why belief in grammar means belief that our understanding horizon exhausts all possible kinds of understanding. Describing and investigating the limits of a horizon is unavoidably done by and with some language, we cannot go beyond this. And yet, some metaphysical problems come up from theoretical approaches that consider that how we name the things or how we speak about our relations (a grammatical necessity, for example, to have subject to an action ${ }^{23}$ ) could be grounded beyond and far these relations. That is again a radical critique: we cannot go beyond our limits, even to ground it. That is why our grounds are ultimately ungrounded.

The second of Nietzsche's negation goes in the same direction: this critique does not concern the antithesis of the "thing in itself" and phenomenon, because there are no parameters for a distinction like that. Our constraints are not founded in a structure of a transcendental subject that we could describe and delimit precisely; they go beyond, they entail our whole life, they are this shared and situated hori-

\footnotetext{
${ }^{23}$ See BGE $17 / 34$
} 
zon that allows any understanding about our own condition. Conditions that Nietzsche considers have become necessary to permit the human life in its social, common features, i.e., shared with the other.

At this point Nietzsche says something surprising: "and even what is here called "utility is ultimately also a mere belief" (and just so seems to be an important reply to Richardson). Glearly, Nietzsche's main argument in the aphorism is that these transcendental features, together with language and consciousness were only developed because it was useful for a specific kind of animal: the human being. And it was exactly what grounded Richardson's claim that Nietzsche was using a kind of Darwinian explanation to discuss that. Nevertheless, as he concludes the aphorism Nietzsche suggests that even his key to reading that phenomenon is still a mere belief. These words were what he had used before to characterize this feature of the human condition that is always already articulating some preunderstanding to comprehend or to explain the world. Far from disqualifying the previous description, what Nietzsche does here is assume that even his explanation of the "phenomenalism and perspectivism" implies some kind of circularity ${ }^{24}$. This is important since it shows that more important to Nietzsche that his "positivist" explanation about the emergence of the human beings, consciousness and language, he is concerned to assume this human condition is insuperable (and of course it includes his own explanation). Han-Pile seems to be more aware about that when she defends that the Nietzschean position has some transcendental feature once the human constraints cannot be 
reduced to any empirical explanation, but rather any empirical attempt to verify it already needs to employ it, and that is why it is "impossible to identify them with any particular set of practices" (Han-Pile 2009, p. 195).

In this sense, Nietzsche rejects the Kantian idea that the description of the structure of transcendental reason as synthetic a priori guarantee of security, necessity or universality, since these features are consequents of contingents events: historical, social and natural "development of man" - And yet, he assumes that our knowledge is always finite. Even when he tries to describe how these limitations become from contingent events, he cannot surpass it. Nietzsche pretends to retain the idea there is something that grounds our perception of the world, but that we cannot ground it ultimately since we always already meaningfully perceive $i^{25}$. Here the hermeneutics aspect of Nietzsche's thought starts to become clearer. What Han-Pile calls "deflationary transcendental" seems to be better understood when its evidently hermeneutic aspect is recovered.

\section{HERMENEUTICS AS RADIGALIZATION OF THE TRANSCENDENTAL PROJECT}

No one doubts one of the most important features of the

\footnotetext{
${ }^{25}$ GS 374: "Our new 'Infinite.' How far the perspective character of existence extends or indeed whether existence has any other character than this; ... that cannot be decided even by the most industrious and most scrupulously conscientious analyses and self-examination of the intellect; for in the course of this analysis the human intellect cannot avoid seeing itself in its own perspectives, and only in theses. We cannot look around our own corner: it is hopeless curiosity that wants to know what other kinds of intellects and perspectives there might be: ... But I should think that today we are at least far from the ridiculous immodesty that would be involved in decreeing from our corner that perspectives are permitted only from this corner. Rather has the world become 'infinite' for us all over again inasmuch as we cannot reject the possibility that it may include infinite interpretations [...]” (p. 336-337). I shall discuss this aphorism ahead.
} 
hermeneutic tradition is the idea of the hermeneutic circle. In a traditional formulation, hermeneutic circle concerns the interdependence between the part and the whole. We can only understand the meaning of the whole from understanding the meaning of each part, and yet, we can only understand each part in connection with the whole. In a stronger formulation, we could claim that the hermeneutic circle is the recognition that we cannot seek meanings beyond the whole that defines each part in its codetermination. Or that finitude and truth, unlike the metaphysical tradition of thought, are not conflicting concepts. It assumes therefore the idea of truth as correspondence is only possible from a limited horizon that allows that something appear as something. However, the circular character is already present in the transcendental project itself. Kant in the Prolegomena assumes this circularity between the parts and the whole as the characteristic of the critique project:

As there is nothing outside pure reason which could correct our judgement within it, the validity and use of every part depends on its relation within reason itself to other parts, and, as in the structure of an organised body, the purpose of every member can only be deduced from the complete concept of the whole (Kant 1953, p. 13).

It is clear enough from where comes its circularity. The critique cannot try to justify itself beyond the limits that it presumes to assume. Since for Kant human reason is what defines the condition (and so, the limits) of the human knowledge, this investigation needs to be restricted by this own character that respects this limitation. Kant presumes to do this by showing that the synthetic judgments a priori are possible in metaphysics exactly because they are only concerned with the structure of the human reason itself, both in intuition and understanding. In this sense, the cir- 
cularity could be considered as a characteristic of the transcendental inquiry as such. ${ }^{26}$ Indeed, as Malpas argues "It is, in fact, the synthetic a priori structure of transcendental reasoning that leads directly to a form of circularity in the transcendental project that seems to lie at the very heart of that project. Moreover it is a circularity that Kant himself seems to recognize." (Malpas 1997, p. 8). But if it is so, why consider hermeneutics as a radicalization of the transcendental project rather than simply consider it as a kind of transcendental inquiry?

Heidegger and Gadamer have assumed the importance of the Kantian heritage to their projects. Gadamer, for example, says in the Introduction of Truth and Method, using a Kantian formulation, that hermeneutics "asks about how is understanding possible?" (Gadamer 1975, p. XVIII). However, they claim for some shift in this project when they consider it a more radical questioning. Heidegger says:

If we radicalize the Kantian project of ontological knowledge in the sense that we do not limit this problem to the ontological foundations of the positive sciences [...] but as the radical and fundamental question concerning the possibility of understanding being in general, then we shall arrive at the philosophical fundamental problematic of Being and Time (Heidegger 1997, p. 289).

What is at stake here, beyond the Heidegerian vocabulary of "understanding of being in general", is that the hermeneutic of facticity carried out in Being and Time is concerned to show us as "being-there"; that is, how the

\footnotetext{
${ }^{26}$ Indeed it has been claimed by Malpas that " [...] if transcendental inquiry is concerned to lay out the structure of experience, then such inquiry should not be taken as committed to claims about any realm beyond experience or about the relation between experience and such realms." (MALPAS 1997, p. 8).
} 
human condition is always already situated factually in a specific understanding of a shared world. It means that our existence is essentially interpretative and always dependent on a finite horizon. And in this sense, even the theoretical approach of Kant that attempts to ground reason as the limits of our knowledge already entails a really specific way of understanding the human being, knowledge, subject and objectivity. In this sense, if on one hand Kant is aware of the circularity of the transcendental project since it cannot go beyond itself, he "fails" to grasp the radicality of this circularity, since he did not assume as his project, his way of positing subject-object, is already fruit of an understanding and not the ultimately reality of man. Since he fails to see it, he attempts to defend the universality and necessity of the description of the structure of the reason and loses sight how this understanding of the human being as transcendental subject is already a special case of the human understanding. It is exactly this fore-structure of the understanding with which hermeneutics is concerned. ${ }^{27}$

As we saw before, it could be understood in terms of the Nietzschean critique of the "faith in grammar" of the philosophers. It takes a special case of understanding as the ultimately reality and discusses problems concerning this interpretation without being aware that it is already limited by a specific horizon. Nietzsche was fully aware of our situated condition that cannot try to bound itself. Perhaps the best place statement of this is still aphorism 374 of The Gay Science:

How far the perspective character of existence extends or indeed whether existence has any other character than this; [...] that cannot

${ }^{27}$ See about that Lafont (2007, p. 105). 
be decided even by the most industrious and most scrupulously conscientious analyses and self-examination of the intellect; for in the course of this analysis the human intellect cannot avoid seeing itself in its own perspectives, and only in theses. We cannot look around our own corner: it is hopeless curiosity that wants to know what other kinds of intellects and perspectives there might be: [...] But I should think that today we are at least far from the ridiculous immodesty that would be involved in decreeing from our corner that perspectives are permitted only from this corner. Rather has the world become 'infinite' for us all over again inasmuch as we cannot reject the possibility that it may include infinite interpretations [...] (NIETZSCHE 1974, p. 336).

Thus, Nietzsche assumes the radical circularity present in the transcendental project of the critique of the human condition, in a way that goes beyond the Kantian pretension of describing this structure in universal terms. Rather Nietzsche points out this finite character of our own situation that cannot avoid implying "perspective forms" to describe its perspectivism. But since we cannot argue that these constraints are universal or necessary, we can take into account the hypothesis that there are infinite ways to understand reality. And it is from this hypothesis that the Nietzschean vindication of the perspectivism arises. As Alan Schrift has put it, perspectivism in Nietzsche is a "conclusion regarding human finitude: because human beings are situated bodily at a particular point in space, time, and history, their capacity for knowledge is inevitably limited" (Schrift 1990, p. 146).

In this sense, more decisive than the way Nietzsche tries to describe our constraints in "physiological, instinctual and socio-historical" terms (Idem) is his insistence that every description is already limited by some constraints. This characteristic circularity of every interpretation, understanding and even critique is therefore not only an episte- 
mological problem, but rather a feature of our finitude as such.

Nietzschean thought is "hermeneutical" since Nietzsche is not only concerned to ground the limits of knowledge in a Kantian sense, but to recognize the limits of the every human experience. As Han-Pile shows, the fact that Nietzsche does not strongly distinguish between the forms of sensibility and the pure concepts of understanding "may indicate that Nietzsche does not think that it is possible to consider sensory content independently from some form of conceptualization... yet such conceptualization should not be seen as requiring a full blown, verbal and consciously articulate use of concepts." (Han-Pile 2009, p. 18). Nietzsche's aim is to show how every human relation towards the entities presupposes a pre-understanding, a previous way to see (perspective) this entity that allows us to see it at all.

When he defends, for example, that "All experiences are moral experiences, even in the realm of sense perception" (NIETZSCHE 1974, p. 174) what is at stake is exactly this "foreground law" 28 , this understanding of the entities, that in a common Nietzschean formulation "creates a world"29, and allows something as sense perception. Only from a determined meaningful horizon we can even have something as a "sense perception". For us to recognize something as sense perception we already need some horizon to make it meaningful. Nietzsche uses the term "moral" to describe our "pre-understanding of being" (in a Heideggerian formulation) for two main reasons: first of

\footnotetext{
${ }^{28}$ See BGE 62

${ }^{29}$ See BGE 4/ 9: “... as soon as a philosophy begins to believe in itself. It always creates the world in its own image, it cannot do otherwise;" /See also BGE 21.
} 
all, for the normative character present in the idea of moral. This is that pre-understanding delimits how the entities can appear, and in this way, how the entities should be at all. As a second reason, the idea of moral points out also the character ungrounded of this ground, as Nietzsche says:

Every morality, as opposed to laisser-aller, is a piece of tyranny against both 'nature' and 'reason'. But this in itself is no objection; for that, we would have to issue yet another decree based on some other morality forbidding every sort of tyranny and unreason. What is essential and invaluable about every morality is that it is a long compulsion (NIETZSCHE 2002, p. 77).

Morality for Nietzsche is this compulsion or these constraints which posit "something as something" but at the same time is a kind of "tyranny", of arbitrary law, since we cannot justify it beyond itself. It is against "nature" and "reason" because it can be grounded neither as natural law nor by some structure of reason. And yet, both come between quotations marks, because morality constrains the possibility of some understanding of what means nature or reason at all. There is no way to give reason to this "law" since it delimits our own way to reasoning.

This circularity therefore prevents every kind of untimely justification, truth or even proofs since all these ways presuppose a pre-given delimitation of a totality within which such things as justification, truth and proof become possible. But this ungrounded character of our understanding is not an objection against it, as Nietzsche says any objection would already presuppose a "morality" from which something as "tyranny and unreason is impermissible". In this sense it is not a problem for knowledge, nor for the comportment of human being, rather, this is what allows it at all; it is how something becomes possible as a human life. 
Justifications, truth and proofs are possible within a horizon. And "morality", as this delimiting horizon, has always a shared and common character. Nietzsche calls attention to the fact that philosophers have historically disregarded completely these limitations which in some sense seems to be the own "human nature". The continuation of aphorism 188 makes it clear:

The fact that, for thousands of years, European thinkers have been thinking only in order to prove something (these days it is the other way around: we are suspicious of any thinker who "has something to prove") - the fact that the results which were supposed to emerge from their most intense contemplations were in fact already firmly established [...] We can look at every morality in the following way: whatever "nature" it contains teaches us to hate the laisser-aller, the all-too-great freedom, and plants in us the need for limited horizons and the closest tasks. It teaches a narrowing of perspective and so, in a certain sense, stupidity as a condition for life and growth.

[...] - this seems to me to be the moral imperative of nature, which is clearly neither "categorical," as the old Kant demanded it to be (hence the "or else"-), nor directed to the individual [...] but rather to peoples, races, ages, classes, and above all to the whole "human" animal, to the human (NIETZSCHE 2002 p. 78-79).

The demand for proofs by thinkers ignores that to prove something we already need to be working within a pre-given meaningful framework. We need "always know in advance" to be able to question and to argue. Therefore morality is here considered as this necessary preunderstanding, these prejudices that allow every kind of interpretative engagement. And in this regarding it is the own "nature" of the human being, who is always from a limited horizon, and from the "narrowing of perspective". This permits human life as such, it is its condition of possibility, but neither biological sense, nor in a Kantian sense, rather in the hermeneutic sense of an understanding of that exist- 
ence $^{30}$. And yet this recognition of the limits of every preunderstanding that permits our existence is not an imperative to human as a subject, as individual, but it is regarded with this "always already" shared situation. If we go further and try to formulate it in a more Heidegerian terms, we could say: these constraints are addressed to the human being as "ek-sistent", that is, always as being-there, in a world, with-others. A limiting horizon, a "morality" is a shared world. To use Gadamer's vocabulary, it is the "universality of the hermeneutical problem" 31 . Nevertheless, it is nothing but the assumption of our limited and historical "nature", condition or place.

\section{TRUTH AND FINITUDE}

The "fragmented" character of Nietzsche's work, written mainly in aphorism style, is responsible for a special difficulty in the interpretation of his work as a whole. To interpreter as a whole means here neither to try thinking a philosophical system of Nietzsche, nor defining some words as fixed and unequivocal concepts. Rather it points out the attempt to hermeneutically follow the work's horizon of meaning; as a philosophical thought that might be meaningful as a unit, a totality. This challenge to relate in some

\footnotetext{
${ }^{30}$ A look at the entire aphorism makes quite clear that Nietzsche is not speaking about life in a biological sense, but that he is concerned with the development of the history of the philosophy as expression of a kind of existence of the human being.

${ }^{31}$ Of course, my intention here is not to say that the philosophy of Nietzsche could be reduced to the philosophy of Heidegger or Gadamer. I think that such reduction as this is neither possible, nor desirable. There are many special themes or concerns that these thinkers do not share, as well as themes and variations even throughout the work of each philosopher that are rich in nuances, and should not be disregarded. All I am trying to do with some of the mixed formulations in this paragraph is to show that there is some element that seems to be common in these authors, and it is exactly what I called the "radical recognition of our finite situation" and the hermeneutic consequences derived therefrom.
} 
interpretative sense different "theses" has occupied many scholars, since the first interpretations of Nietzsche's philosophy were delivered. Of course, some "theses" are harder to make sense than others when thought as a whole. No doubt in the heart of this problem is the will to power doctrine, and usually how to make it work along the "theory of error" and with perspectivism.

As has been shown, this interpretation grasps perspectivism as the assumption of the unavoidable limits of the human existence following its finitude. This radical finitude (and thereby historical and hermeneutical existence) can be assumed as the only "nature of human beings". To be concerned with it is to give up any other strong affirmation about the nature of entities, of the world and even of the human being. In the same sense, the theory of errors seems, as Green has shown, to assume the antinomies of any effort to ground our knowledge. In this sense, Nietzsche maintains the words truth and knowledge as used for the tradition in a strong sense: to define a metaphysical idea, namely to have access to a "secure, necessary, eternal and universal" account of the entities ${ }^{32}$.

Thus, the theory of error works as a "negative formulation" of the possibility of grounding knowledge, denying both the realist version as well as the attempt of the transcendental idealism. As the horizon, the morality, from where we perceive the world is itself ungrounded, what we consider as the truth is not more than illusion, lies, error. And on the other hand, the perspectivism works as a "positive formulation" of the same thesis. Perspectivism is an attempt to show that the limits and circularity of any

${ }^{32}$ See GS 347 
knowledge is not a problem, but rather what allows something as knowledge at all, since this horizon is what allows some perception and knowledge of the entities. Therefore, truth as correctness is possible but only limited within some perspective ${ }^{33}$, this shared and "created world".

Following this interpretation, it would not make much sense to read the will to power as a strong metaphysical description "of reality in itself" or as the determination of "the being of the beings". Even if this description could be thought as a kind of consequence of the perspectivism, and thereby a try of "ontologizing" the perspectivism, assuming it as the character of the reality as such and denying any kind of "suprasensory" foundation beyond it, it would be still quite contrary of the theory of error and the perspectivism as the description of the human condition limited by transcendental constraints, as we saw previously. One possible solution, in order to make them compatible, would be to assume a distinction between perspectivism and will to power ${ }^{34}$, and yet its correlation. It is undeniable that will to

\footnotetext{
${ }^{33}$ In this sense, this interpretation is really close to the Han-Pile's hypothesis: "My hypothesis is that the real target of Nietzsche's skepticism about knowledge may not be so much the possibility of limited objectivity resulting from the use of perspectival conditions as two kinds of illusions: on the one hand, our inclination, motivated by the drive for survival, to ignore the fact that our experience is determined by transcendental features, which results in metaphysical realism or in nave empirical realism; on the other, the tendency of some philosophers (in particular Kant) to take what are merely features for constraints, and to think that universal and necessary knowledge is possible, when in fact only relative forms of objectivity are legitimate." (2009, p. 205).

${ }^{34}$ This distinction was claimed by some interpreters from Kaufmann to the recent version of Doyle. Kaufmann claimed that the will to power is neither metaphysical nor positivist since it would be incompatible with the assumption of the critical position of Nietzsche that affirms that "the world is unknowable" against the "unlimited ambition" of the tradition (Kaufmann 1974, p. 204). He consider it as a "psychological hypothesis" (p. 185) but that in consonance with the project of German Idealism it would be concerned to as well as the function of the cosmos. In order to defend it, he makes an important comparison between Nietzsche and Hegel (See specially p. 229 onwards). Doyle suggests another kind of distinction between both theories, she claims that the will to power is a metaphysical theory but derived from perspectivism, a theory that could be "intra-contextually warranted rather than justified outside all contexts." (2005, p. 10).
} 
power theory's scope has some strong claims about world, nevertheless, we could consider all this as an endeavour to ground the reality in a "first level". That is, Nietzsche, as philosopher, has a strong pretention to delimit a new horizon of intelligibility. He wants "to create" a world (to posit a horizon) where new human thought and comportments become possible. This ambition however is compatible with his critical thought of a "second level" (i.e., concerned with a transcendental limitation), since it assumes that it would be the only other way to delimit the horizon within our knowledge and perceiving becomes possible. And yet, he presumes that this new horizon should be more compatible with its own finitude. This means that Nietzsche pretends to define a new ground and, at same time, he is aware of the ultimately ungrounded character of it.

This helps us understanding some puzzle aphorism of Beyond Good and Evil as the following:

[...] this "conformity of nature to law," which you physicists are so proud of, just as if - - exists only because of your interpretation and bad "philology." [...] this is interpretation, not text; and somebody with an opposite intention and mode of interpretation could come along and be able to read from the same nature, and with reference to the same set of appearances, a tyrannically ruthless and pitiless execution of power claims.

[...] Granted, this is only an interpretation too - and you will be eager enough to make this objection? - well then, so much the better (NIETZSCHE 2002, p. 22-23).

This aphorism is interesting because it begins with a critique to the physicist, therefore, to naturalistic approaches, which consider that some kind of positivism would be free from pre-understanding of nature. He claims that what they call nature is not a fact, but an interpretation. Following all our debate until here, Nietzsche is pointing 
out the fact that the physicists already need a horizon that allows them to see the nature as they do it. But this is only interpretation; there is no way to justify the naturalistic interpretation of the world as a "privileged perspective". The world could become "visible" by other interpretation, for example, as the will to power. As it is clear, Nietzsche wishes to dispute the horizon by which we think and live, he defends that a naturalistic approach is a "bad interpretation". However, this dispute could not be waged beyond our finitude. Rather, the will to power pretends to be a better interpretation since it would be more auspicious to be aware about our limitations.

As Green puts it the will to power, understood as a theory of absolute becoming, cannot be more than a kind of "telescoped version" (2002, p. 83) of the Nietzschean critique that assumes the antinomies in any strong epistemological vindication. And in this sense, is characterized by a special circularity, as every possible human explanation. It is only an interpretation even when Nietzsche supposes that it is better for the "free spirits" who have become aware of our situation as the radically finite and historical one. In this sense, more important than Nietzsche's doctrine of will to power (as a new horizon that denies suprasensory principles) ${ }^{35}$ is his critique that will to power is itself still an interpretation.

\footnotetext{
${ }^{35} \mathrm{We}$ could say, in this sense, that the Heideggerian interpretation of Nietzsche is concerned exactly with how Nietzsche could indeed have done so, once he "gives voice" to the contemporary world of technology by his will to power ontology.
} 


\section{FINAL GONSIDERATIONS OR AN OUTLINE OF A REPLY TO GRONDIN}

As this text tries to show, Nietzschean philosophy is strongly defined by a Kantian heritage and at same time by a radicalization of the project of the critique as such. Nietzsche shows how Kant fails to see that his attempt to describe the categories and forms of intuition as pure and a priori (and thereby necessary and universal) already presuppose a particular interpretation (or a "faith in grammar", another kind of a priori), that articulates a horizon of the intelligibility as the ultimate reality (even in a transcendental idealism version, where the structure of subject is assumed as a kind of ultimate reality). And in this sense, Nietzsche searches for a more critical approach since it is concerned with the limits of all human existence, which allows knowledge and comportment within a specific horizon. As it was argued, these conclusions arise from Nietzsche's assumption of our finitude as the only possible parameter to think the human being. And thereby he denies the possibility of any kind of truth in a metaphysical sense that tries to go beyond this limitation. At the same time, he assumes that this limited and shared version of the world is what allows to us any perception the world and in this sense permits what we call "human life". That is exactly why this text defends that Nietzsche's is a hermeneutical thinking rather than only deflationary transcendental, for example. Therefore, this text agrees with the Green's conclusion that:

[...] in seeking higher-order reflection on our judgments, Nietzsche once again shows himself to be in the grip of the transcendental tradition. Naturalistically inclined philosophers today can be distinguished by their desire not to adopt such a higher-order perspective. 
They advocate an unreflective reliance on naturalism that Nietzsche finds unsatisfactory. For that reason alone, we should be skeptical about whether Nietzsche's interests are theirs" (Green 2002, p. 165).

Here is exactly where the importance of a hermeneutical interpretation of Nietzsche lies. A naturalist account of the human condition (as well as the pragmatist, relativistic, sociological or any other that assumes that the "empirical horizon" is the adequate way to describe the reality and disregards that it is still a horizon, i.e., still an interpretation) fails exactly in recognizing its own limitations, since it can only be carried out within a specific hermeneutical horizon, "morality" (in the discussed Nietzschean sense) or "understanding of being". This account might, at first glance, seem quite close to Nietzschean interest to avoid a metaphysical foundation in a suprasensory world, and indeed it is. But it does not see the most important claim about the perspectivism, precisely the circularity derived by its finitude. As says Zarathustra: "the closest cleft is the last to be bridged" (NIETZSCHE 2006, p. 82). We could, in a metaphorical way, say that this kind of account is a kind of heir of the "will to power" doctrine, but that it fails to recognize itself as one more "created world" only. That is so not because "all is invented", but rather because even seeing the world as invention is only possible within a particular/historical/situated pre-understanding of the world, i.e., from and by some perspective. There is no privileged standpoint at all; every inquiry is always already situated. ${ }^{36}$

In this sense, the discomfort of Grondin with some

\footnotetext{
${ }^{36}$ For a discussion of how hermeneutics is concerned with the task to become aware about our situatedness in a place, see Malpas (2014).
} 
readings of hermeneutics in a "relativistic sense" is justified, but I would like to suggest that better than put up some resistance to this "Nietzscheanization of hermeneutics" (Grondin 2010, p. 107) we could to do quite the reverse. That is, put up some resistance to the reading of Nietzsche as a relativist, and insist in the importance of the radical critique carried out by hermeneutics. In other words, we should insist furthermore in a "Hermeneutization of Nietzsche". And in this sense, we could better see this aspect of the Nietzschean philosophy that claims that questioning our condition 'always already' occurs within a limited horizon. That is to say, it is important to confront some versions of Nietzsche's philosophy that disregard his concern for our radical finitude throughout his work. To be aware about our finitude is not a relativistic consideration that "there is no truth at all" but rather a hermeneutical awareness that our truths are ultimately ungrounded (even these "contemporary truths" that pretends strongly to deny any kind of truth). The question is, once again to use a Heideggerian formulation, nothing but how to enter in the right way into this circular aspect of Nietzsche's philosophy.

\section{REFERENGES}

\section{Works by Nietzsche:}

BGE: [1885] Beyond Good and Evil. Trans. Norman, J. Cambridge: Cambridge University Press, 2002.

GS: [2 sd. ed.1887] The Gay Science. Trans. Kaufmann, W. New York: Vintage Books, 1974. 
HH: [1878] Human, All Too Human. Trans. Hollingdale, R.J. Cambridge: Cambridge University Press, 1996.

Z: [1883/84/85] Thus Spoke Zarathustra: A book for all and none. Trans. Adrian del Caro. Cambridge: Cambridge University Press, 2006.

\section{Commentators:}

Allison, H. Kant's Transcendental Idealism: An Interpretation and Defense. New Haven \& London: Yale University Press, 1983.

Ansell-Pearson, Keith. Nietzsche and the problem of the will in modernity. In: . (Ed). Nietzsche and Modern German Thought, pp. 165-191. London and New York: Routledge, 1991.

. Incorporation and individuation: on Nietzsche's use of phenomenology for life. In: Journal of the British Society for Phenomenology, vol. 38. N. 01, p.61-89, January, 2007.

Babich, Babette. "Thus Spoke Zarathustra" or Nietzsche and Hermeneutics in Gadamer, Lyotard, and Vattimo. In: MALPAS; ZABALLA (ed.). Consequences of Hermeneutics: fifty years after Gadamer's Truth and Method, pp. 218 -243. Evanstons and Illinois: Northwestern University Press, 2010.

. Heidegger's Will to power. In: Journal of the British Society for Phenomenology, vol. 38. N. 01, p. 37-60, January, 2007.

Bailey, Tom. Nietzsche the Kantian?. The Oxford Hand- 
book of Nietzsche. Ed. by John Richardson and Ken Gemes. Online Publication Date: Dec 2013. - DOI: 10.1093/oxfordhb/9780199534647.013.0007.

Davey, Nicholas. Lest we forget: the question of being and philosophical hermeneutics. In: Journal of the British Society for Phenomenology, vol. 40. N. 03, p. 239-254, October, 2009.

- 'Hermeneutics and Nietzsche's early thought'. In: Ansell-Pearson, Keith (Ed). Nietzsche and Modern German Thought, p. 88-118. London and New York: Routledge, 1991.

Doyle, Tsarina. Nietzsche on Epistemology and Metaphysics: The World in View. Edinburgh University Press, 2005.

Gadamer, H. Truth and Method. Trans. Ed. Garrett Barden and John Cumming. New York : Seabury Press, 1975.

Green, Michael S. Nietzsche and the Transcendental Tradition. Urbana and Chicago: University of Illinois Press, 2002.

Grondin, Jean. Must Nietzsche be Incorporated into Hermeneutics? Some Reasons for a Little Resistance. In: Iris, II, 3, p. 105-122, April, 2010.

Han-Pile, Béatrice. Transcendental Aspects, Ontological Commitments and Naturalistic Elements in Nietzsche's Thought. In: Inquiry: An Interdisciplinary Journal of Philosophy, $\quad 52: 2, \quad \mathrm{p} \quad 179-214, \quad 2009$. DOI:10.1080/00201740902790243.

Heidegger, M. [1927-28] Phenomenological Interpretation 
of Kant's Critique of Pure Reason. Trans. Parvis Emad and Kenneth Maly. Bloomington \& Indianapolis: Indiana University Press, 1997.

Kant, I. [1783] Prolegomena to any future metaphysics that will be able to present itself as a science. Trans. by Peter G. Lucas. Manchester: University of Manchester, 1953.

. [1781/87] Critique of Pure Reason. Trans. by Norman Smith. London: Macmillan \& co Ltd, 1964.

Kaufmann, Walter. Nietzsche: Philosopher, Psychologist, Antichrist. Princeton: Princeton University Press, 1974.

Lafont, Cristina. Heidegger and the Synthetic A priori. In: Crowell, Malpas (Eds) Transcendental Heidegger, pp. 104-118. California: Stanford University Press, 2007.

Lopes, Rogério Antônio. Ceticismo e vida contemplativa em Nietzsche. 2008. 573p. Phd Thesis in Philosophy. Universidade Federal de Minas Gerais, Belo Horizonte, 2008.

Malpas, Jeff. Place and Situation. In: Malpas, J. and Gander, H. (Eds), The Routledge Companion to Philosophical Hermeneutics, 2014.

. Heidegger's Topology of Being. In: Crowell, Malpas (Eds) Transcendental Heidegger, p. 119-134. California: Stanford University Press, 2007.

. The transcendental circle'. In: Australasian Journal of Philosophy, 75: 1, p. 1-20, 1997.

Mattioli, William. O devir e o lugar da filosofia: alguns aspectos da recepção e da crítica de Nietzsche ao idealis- 
mo transcendental via Afrikan Spir. In: Kriterion, Belo Horizonte, $\mathrm{n}^{\mathrm{o}}$ 128, p. 321-348. December, 2013.

. From transcendental idealism to naturalism: an ontological leap into time based in a phenomenology of representation. In: Cadernos Nietzsche, n.29, vo.II, p. 221$270,2011$.

Picht, George. Nietzsche: Thought and the truth of history. In: Journal of the British Society for Phenomenology, vol. 38. N. 01, p. 4-36, January, 2007.

Pippin, Robert B. Nietzsche, Heiddeger, and the metaphysics of modernity. In: Ansell-Pearson, Keith (Ed). Nietzsche and Modern German Thought. p. 282-310. London and New York: Routledge, 1991.

Richardson, John. Nietzsche and transcendental argument. In: Kriterion, Belo Horizonte, $n^{\circ} 128$, p. 287-305, December, 2013.

Small, Robin. 'Nietzsche, Spir, and Time'. In: Journal of the History of Philosophy, Volume 32, Number 1 pp. 85102, January, 1994.

Schrift, Alan. Nietzsche and the question of interpretation: between Hermeneutics and Deconstruction. London and New York: Routledge, 1990.

Stack, George J. Kant, Lange, and Nietzsche: critique of knowledge. In: Ansell-Pearson, Keith (Ed). Nietzsche and Modern German Thought, p.30-58. London and New York: Routledge, 1991.

Walker, John. Nietzsche, Christianity, and the legitimacy 
of tradition. In: Ansell-Pearson, Keith (Ed). Nietzsche and Modern German Thought, p.10-12. London and New York: Routledge, 1991.

Zuckert, Rachel. Projection and Purposiveness. In: Crowell; Malpas (Eds.) Transcendental Heidegger, p. 213-231. California: Stanford University Press, 2007. 